\title{
Research of Information Literacy of Chinese Public Security Management Students
}

\author{
Jin WEN ${ }^{1, a,{ }^{*}}$ \\ ${ }^{1}$ Department of humanities and management, JiangXi Police College \\ NanChang, China \\ awdtre@163.com
}

Keywords: Information literacy, Public security management, Chinese police college, Evaluation.

\begin{abstract}
According to the unified evaluation criteria of information literacy lack of Chinese police college and the normalization of evaluation mechanism, this paper puts forward an information literacy evaluation index system that meets a suitable target and demand of the development of Chinese police college with the construction of function evaluation and learning evaluation of the online platform, and the design of information literacy evaluation scheme lets the teachers and students of police college to pay more attention to the information literacy.
\end{abstract}

\section{Introduction}

With the advent of the information age, information literacy has become the basic literacy of college students [1][2][3]. It is the basis of learning and scientific research for the contemporary college students to understand the information resources and master the methods and skills of searching, acquiring, managing and using information resources. With the gradual development of the digital learning environment, mobile, learning oriented teaching methods to students as the center gradually increased, the information literacy education in Colleges and universities need more and more information literacy level and the needs for students to carry out individualized teaching [4][5].

For the information literacy evaluation criteria and the specific content of the evaluation, the information literacy education is more developed countries and regions have established a relatively common standards and frameworks, and there are many research results in China[6][7][8]. Tsinghua University in 2005 issued a "University Information Literacy Index System" in Beijing that learned from the existing standards and established the index system in 7 dimensions by Delphi. In 2008, the Education Ministry of Chinese put forward an "Index System of College Students' Information Literacy"[9][10].

Therefore, this paper studies the information literacy evaluation index system which is suitable for the development needs of China's public security colleges and universities, and constructs the information literacy evaluation mechanism to improve the information literacy of teachers and students [11].

\section{Evaluation of Information Literacy}

The evaluation of information literacy mainly includes questionnaire investigation, examination paper examination, behavior evaluation and student evaluation, etc., and 
their advantages and disadvantages are compared in Table 1. Some colleges and universities also try to use a variety of evaluation forms to improve the effectiveness of the evaluation. For example, the information literacy education in Australian universities to carry out all kinds of evaluation activities, including project evaluation, curriculum evaluation and student evaluation, evaluation content, many aspects of the curriculum evaluation methods mainly include the student evaluation, teaching evaluation, curriculum cooperation colleague teacher feedback evaluation method; student evaluation system including online evaluation, traditional test and questionnaire survey portfolio assessment, with the students, self evaluation, interest group evaluation, the evaluation focus on both results and process [12][13][14].

Table 1. Comparison of advantages and disadvantages of information literacy evaluation

\begin{tabular}{|c|c|c|}
\hline Type of Evaluation & Advantages & Disadvantages \\
\hline $\begin{array}{l}\text { Questionnaire } \\
\text { investigation }\end{array}$ & $\begin{array}{l}\text { Most used; } \\
\text { Simple and easy to design; } \\
\text { Result is intuitive; }\end{array}$ & $\begin{array}{l}\text { There are many subjective } \\
\text { factors; } \\
\text { Lack of ability to measure }\end{array}$ \\
\hline Paper-test & $\begin{array}{l}\text { Easier to achieve the ability to evaluate; } \\
\text { To solve practical problems for the design of } \\
\text { the form; } \\
\text { Be able to demonstrate practical use; }\end{array}$ & $\begin{array}{l}\text { Test paper is single, not achieve } \\
\text { continuous evaluation; } \\
\text { Results only the total score, the } \\
\text { lack of fine analysis; }\end{array}$ \\
\hline Behavior evaluation & $\begin{array}{l}\text { Evaluation form more humane; } \\
\text { Evaluation results are not based on a single } \\
\text { result, but multi face combination, effectively } \\
\text { improve the stability and reliability of the } \\
\text { results; } \\
\text { Evaluation of sustainability, easy tracking } \\
\text { and comparison }\end{array}$ & $\begin{array}{l}\text { Too many subjective factors; } \\
\text { Evaluation criteria are difficult to } \\
\text { unify; }\end{array}$ \\
\hline
\end{tabular}

\section{Construction of Information Literacy Model}

This research design and restructure the index according to the needs of the development of Chinese students and the feasibility of the evaluation, and then establish an evaluation index system of information literacy for Chinese police college, as shown in Table 2. The evaluation index system not only covers the information literacy ability of all aspects, but also considers the students' knowledge and skills in the study and research [15][16]. 
Table 2. Information literacy evaluation index

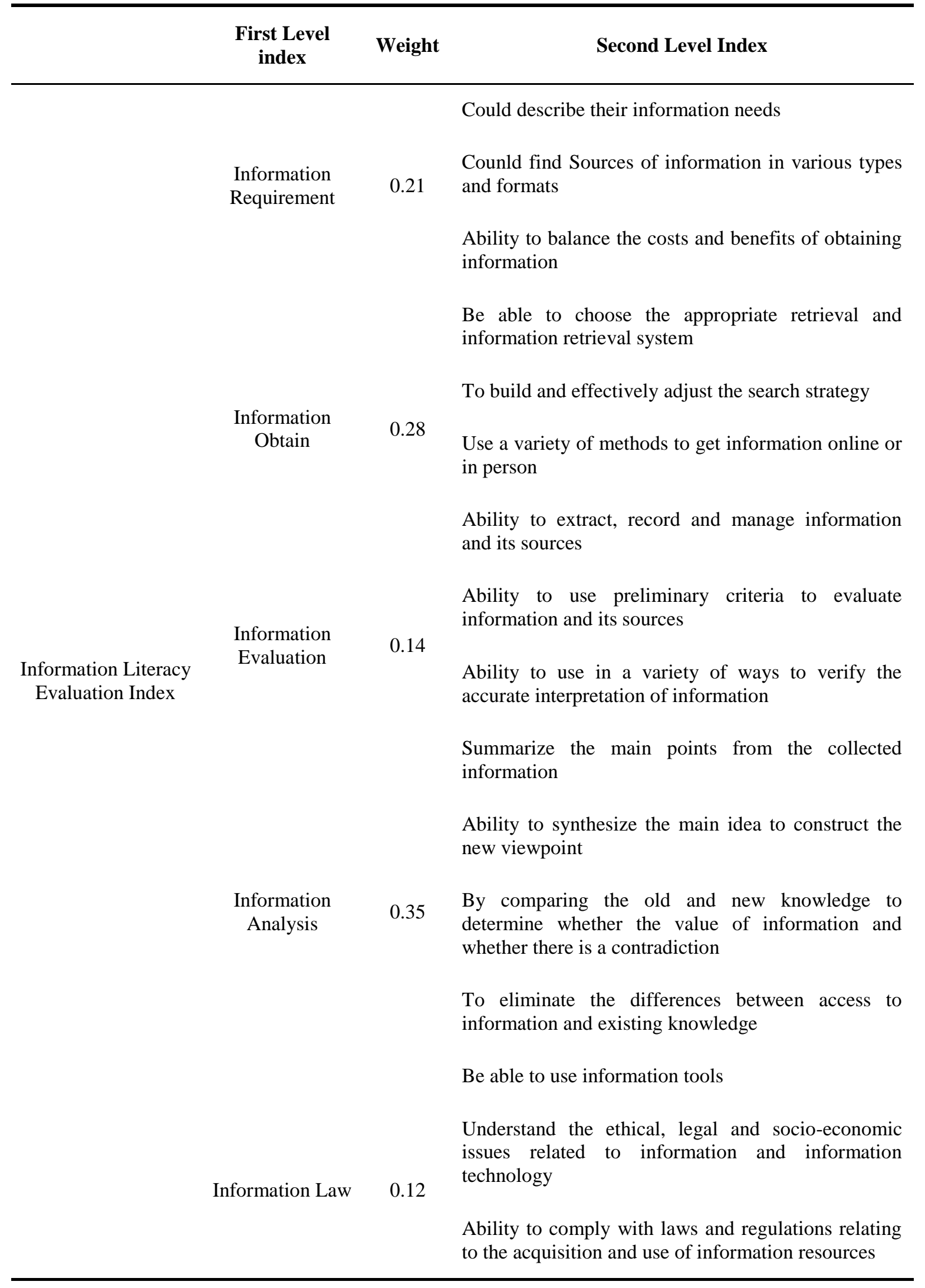




\section{Information Literacy Evaluation Data Analysis}

In the aspect of content design, in addition to part of the information literacy related common problems, most of the problems through solving practical problems to evaluate the level of information literacy, focusing on testing students information consciousness and practical ability, at the same time each question according to the number of standard test contents and refers to the system of two level indexes, and ensure that each indicator has multiple evaluation subject corresponding to reduce the repetition rate of random test paper; in the title form, is easy to realize automatic real-time score test, using multiplechoice questions. On this basis, the use of random test paper evaluation index weight function, according to the difficulty of test selection and index system, a test paper from the corresponding difficulty and test index in the title were randomly sampled in proportion to the questions in the title [17][18].

The overall scores of teachers and students to participate in the evaluation of $56 \sim 60$ as the center of normal distribution, as shown in Figure 1, the average total score is 58.26 points, the total score was 60 points, showing the level of information literacy of teachers and students to participate in the evaluation of the overall basic standards, but there is still great room for improvement. The proportion of the number of participants in the total number of teachers and students in the school is less than $5 \%$, indicating that the overall attention of teachers and students for information literacy and evaluation is still low.

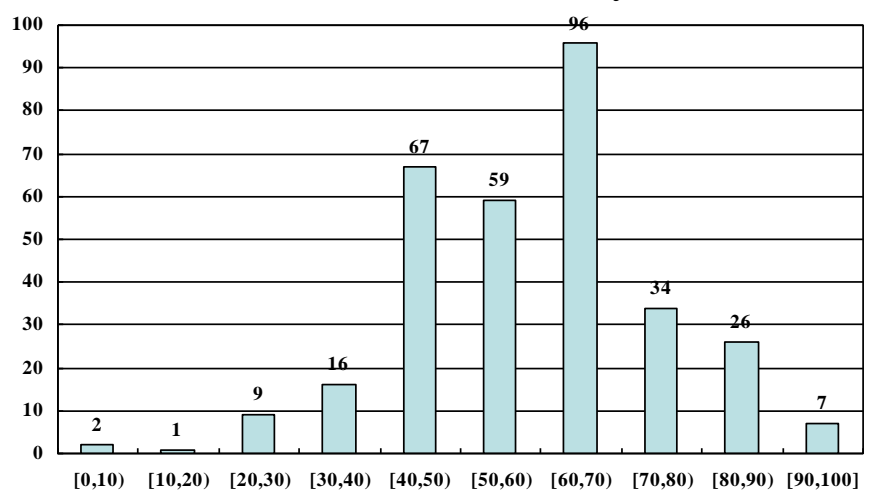

Figure 1. Evaluation of the total score of teachers and students

Each student evaluation will be re randomly generated test paper, so as to avoid the loss of effectiveness in the evaluation of single test was repeated after the problem, let the students learn the knowledge and skills of information after a period of time, can understand information literacy level of their own ascension through the letter test again, but also conducive to change the level of information literacy school students through multiple evaluation monitoring from entrance to graduation period, evaluate the effect of their information literacy education, and to develop targeted programs to improve[19][20].

Participants in the information literacy evaluation of the 5 indicators of the average score were: $54.20 \%, 48.85 \%, 61.20 \%, 74.92 \%, 59.46$. The results show that: in the past, because of lack of information in the evaluation of information literacy education in Colleges and universities in China and the information moral and legal aspects, leading to the ability of students in these two areas is relatively weak and no actual ability of information consciousness and information, in contrast to curriculum resources abundant acquisition shows there is still a lack of students. 


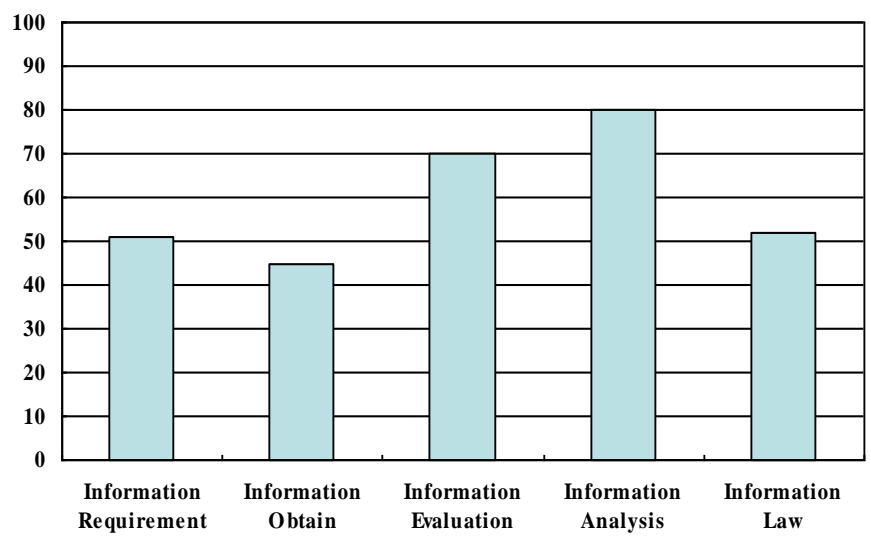

Figure 2. Total score of evaluation index

The results show that, there are still a considerable number of students are still unable to accurately understand their information retrieval and access ability; on the other hand also reflects the impact of existing information literacy education in Colleges and universities on the information literacy level of students is still limited.

The scores of different participants identity can be seen, as shown in Figure 2, in the analysis of information consciousness, information and the scores of participants is close; the information acquisition, information evaluation, information morality and law are more obvious differences. Therefore, in the organization of information literacy training for different objects, according to their information literacy scores for more targeted content design.

In addition, the platform can be built the integration of a large number of online tutorials, lectures, video courseware resources information literacy learning materials and Internet access is free open course resources, evaluation platform will be able to further refine the analysis of the scores of students, identify problems in the information literacy, and push the corresponding learning materials and courseware, online curriculum resources, learning resources and tools needed to quickly find to facilitate students after the completion of the test, the realization of information literacy evaluation service.

\section{Discussion and Future Work}

The existing information literacy evaluation designed a detailed index and weight that could comprehensively evaluate the level of information literacy of public security college students, but the results are mostly a total score. For teachers and students, the score can help them understand whether their information literacy level is qualified or location. However, it is to help them effectively enhance and complement their own information literacy capabilities of the key that lets students to understand their specific strengths and weaknesses and these need to further refine the evaluation. Thus, this paper provides the course content and learning resources for different departments and different grades of students, and to provide a reliable reference for the school is more reasonable and effective planning and formulation of relevant information literacy education development strategy. This paper provides the course content and learning resources for different departments and different grades of students, and to provide a reliable reference for the school is more 
reasonable and effective planning and formulation of relevant information literacy education development strategy.

\section{Acknowledgment}

This author's work is supported by JiangXi Research on teaching reform of higher education(JXJG-15-19-3), JiangXi Science and technology research project of Education Department(GJJ151193), JiangXi Social Science Planning Projects during the 12th FiveYear Plan(14TQ05), JiangXi University Party Building Project(16DJQN065) and JiangXi Police College Scientific Research Project(2016JGZB008).

\section{References}

[1] Li Yaojun. The information literacy of Chinese and American college students standard [J]. Journal of University Library, 2011, (1): 69-71. (in Chinese)

[2] Zhou Meifang. A comparative study on the evaluation criteria of information literacy at home and abroad [J]. Journal of Library Science, 2013, (12): 15-18. (in Chinese)

[3] Zhang Jun. Study on the evaluation index system of Higher Vocational Students' information literacy [J]. Journal of Management Observation, 2014, (16): 144-145. (in Chinese)

[4] Chen Wenyong, Yang Xiaoguang. Research on the standard of students' information literacy ability in higher educatio [J]. Information Science, 2001, 18(2): 611-613. (in Chinese)

[5] Chen Zhi. Construction of the basic application of vocational information literacy training based on computer teaching[J]. Teaching Forum, 2016,32:81-84. (in Chinese)

[6] Zhao Fei. Evaluation of information literacy of college students[J]. Library Forum, 2016,02:106-113+135. (in Chinese)

[7] Shen Qiang. Research on the mode and characteristics of information literacy education in American colleges and universities[J]. Ideological Education Research, 2016,01:124-127. (in Chinese)

[8] Wang Fu. Research on Information Literacy of college students based on Bibliometric Analysis[J]. Review of Education, 2015,05:98-100. (in Chinese)

[9] Li Huimin. Based on the information age of Higher Vocational Teachers' information literacy training[J]. Vocational Education Forum, 2014,14:11-13. (in Chinese)

[10] Liu ran. The impact of the application of information technology on the cultivation of students' information literacy[J]. Computer Engineering and Science, 2014, S1:230233. (in Chinese)

[11] Ren Junxia. Research on the innovation of university information literacy education system in the era of big data[J]. Library and Information Science, 2014, S1:236-238. (in Chinese) 
[12] Yu Ling. Construction of the evaluation index system of College Students' information literacy[J]. China Adult Education, 2013,21:89-91. (in Chinese)

[13]Zuo Feifei. Relevance learning theory and Information Literacy Education under the network environment[J]. Modern Intelligence, 2013,05:6-8. (in Chinese)

[14] Xu Shanshan. Study on the teaching of information literacy based on personal learning[J]. Library Science Research, 2011,03:8-12. (in Chinese)

[15]Zhu Xiaoli. Research on graduate student literature retrieval course based on information literacy training[J]. Library Science Research, 2011,23:62-65. (in Chinese)

[16] Wang Ping. Research on Library Information Literacy Education Based on Elearning[J]. Library Science Research, 2009,11:88-90. (in Chinese)

[17] Li. Analysis on the training mode of public security management talents [J]. Police Education, 2014,04:61-64. (in Chinese)

[18] Yang Yujie. Construction of mobile agent network evaluation model based on learning[J]. Science and Technology Innovation, 2010,10:35-36.. (in Chinese)

[19]Zhang Ping. Study on evaluation model of collaborative learning in network environment $[\mathrm{J}]$. Science and Technology Information Development and Economy, 2010,34:101-103. (in Chinese)

[20] Chen Lihua. Research on student learning evaluation model based on Bayesian network[J]. Science and Technology Information, 2009, 08:374-375. (in Chinese) 